\title{
Pedagogiczne implikacje antropologii teologicznej
}

\section{The Pedagogical Implications of Theological} Anthropology

\begin{abstract}
ABSTRAKT
Autor stawia tezę, że teologiczne koncepcje człowieka, pomimo że niesprawdzalne empirycznie, moga być inspirujace dla pedagogicznej teorii i praktyki. Wśród najważniejszych i najbardziej inspiru¡q̨cych twierdzeń teologicznych wyróżnia stworzenie ludzkiej duszy bezpośrednio przez Boga. Spojrzenie na człowieka jako istotę stworzonq przez Nieskończonq Miłość wskazuje, że relacje (miłość) stanowiq najważniejsza sferę naszego życia. Taka perspektywa pozwala konstruować adekwatnq hierarchię celów, zadań oraz narzędzi wychowawczych i edukacyjnych. Zdolność do tworzenia głębokich, trwałych relacji interpersonalnych powinna być traktowana jako najważniejszy cel wychowania. Nie powinno się też zapominać, że relacje międzyosobowe sq kluczowym czynnikiem (i najważniejszym narzędziem) całej edukacji. Przykładanie wielkiej wagi do technicznych warunków edukacji przy jednoczesnym lekceważeniu znacznie istotniejszych kwestii: osobowości nauczyciela/wychowawcy, może się okazać poważnym błędem.
\end{abstract}

SPI Vol. 23, 2020/1

ISSN 2450-5358

e-ISSN 2450-5366

DOI: 10.12775/SPI.2020.1.001

Nadesłano: 31.12.2019

Zaakceptowano: 3.04.2020

Artykuły i rozprawy 


\section{ABSTRACT}

The author claims that the theological conceptions of humans, even though they are empirically unverifiable (just as is the case with all theology), can be inspiring for pedagogical theory and practice. According to the author, among the most important and inspiring theological statements we can indicate the creation of the human soul directly by God.

Understanding and treating people as beings created by Infinite Love suggests that interpersonal relations (love) are the most important things in a human life. This perspective enables the construction of an appropriate hierarchy of aims, objectives and instruments in upbringing and education. The ability to create deep, lasting, interpersonal relationships should be treated as the most important aim of upbringing. One should never forget that interpersonal relationships are a crucial factor (we may even say the most important instrument) in education. Paying too much attention to technological conditions and information technology tools in education, while disregarding more important issues such as the personality of teacher/educator, would be a grave error.

Wstęp

Czy chrześcijaństwo ma nam jeszcze coś do powiedzenia? Czy ponowoczesne społeczeństwo może oczekiwać jakichś ożywczych impulsów płynących ze studiowania starych, świętych ksiąg? W przekonaniu piszącego te słowa - zdecydowanie tak. Co więcej, owe ożywcze impulsy mogą wykraczać daleko poza ściśle religijne sfery życia. Dla rozwoju naszej wiedzy, przede wszystkim o sobie samych (ze wszystkimi społecznymi zmianami będącymi konsekwencjami tego rozwoju), bardzo wartościowe może się okazać krytyczne spojrzenie z perspektywy uwzględniającej doświadczenia minionych pokoleń. Człowiek zawsze jest dzieckiem swojej epoki - w niezauważalny z reguły sposób jest przesiąknięty jej atmosferą kulturową, myśli jej kategoriami i w oczywisty sposób uznaje za prawdziwe rozpowszechnione w niej przekonania, a czasem przesądy. Niezwykle trudno jest zauważyć błąd w przekonaniach, które uznajemy za oczywiste, a więc $z$ reguły nawet ich nie tematyzujemy. Zjawisko to nasila się jeszcze bardziej wraz $z$ upowszechnianiem się liniowego pojmowania rozwoju (Postman 2002; Sztompka 2012), czyli przekonania, 
że teraźniejszość jest niejako $z$ definicji lepsza niż przeszłość (a przyszłość będzie jeszcze lepsza). W takiej sytuacji niezwykle cenne okazują się spojrzenia z zupełnie innych perspektyw. Źródłem takich ożywczych, krytycznych impulsów mogą być środowiska czy instytucje religijne - takie jak Kościól, który nie tylko czuje się depozytariuszem prawd objawionych (a więc $\mathrm{w}$ swoim zasadniczym rdzeniu ponadczasowych), ale dodatkowo ma za sobą bardzo długą tradycję, kumulującą doświadczenie wielu pokoleń, które przeżywały i w jakiś sposób przez swoje życie filtrowały owe objawione prawdy. Mamy tutaj niejednokrotnie do czynienia $\mathrm{z}$ radykalnie innym spojrzeniem, uwarunkowanym odmiennymi przedzałożeniami i rozwijanym $\mathrm{w}$ ramach innej aksjologii, a dodatkowo wzmocnione autorytetem religijnym. Autorytet ten (oczywiście dla przyjmujących go) może stanowić jednak przyczynę łatwego odrzucenia danych poglądów czy koncepcji, tylko dlatego, że są odmienne od współczesnych, choć z drugiej strony może również skłaniać do głębszego przemyślenia współczesnych koncepcji wychowawczych i krytycznego przyjrzenia się im (czasem aż do poziomu ich przedzałożeń).

Powyższe uwagi charakteryzują ogólne założenia tekstu i przekonania autora, zgadzającego się z Marianem Nowakiem, który twierdzi, że chrześcijaństwo ma ogromny potencjał inspirowania pedagogiki (Nowak 2001). Szczegółowym celem opracowania będzie pokazanie jednej z tez antropologii teologicznej i analiza jej pedagogicznych implikacji w kontekście współczesnych uwarunkowań i trendów wychowawczych. $\mathrm{Z}$ jednej strony stoi za tym przekonanie autora, że wywiedziona z Objawienia (a wielokrotnie przemyślana przez liczne pokolenia) koncepcja człowieka może być źródłem ożywczych impulsów dla pedagogicznej refleksji i praktyki, a z drugiej - przeświadczenie, że mogą to być treści inspirujące także dla ludzi, którzy nie podzielają wiary w Trójcę Świętą czy w dwie natury Chrystusa. Przekonania te będą się odbijać na strukturze tekstu: punktem wyjścia będzie refleksja teologiczna, zarysowanie tezy antropologicznej, ale jej pedagogiczne implikacje będą analizowane w kluczu nauk społecznych i na tle współczesnych społeczno-kulturowych uwarunkowań wychowania. 


\section{Miłość jako ontologiczna podstawa ludzkiego byłu}

W najbardziej ogólnym ujęciu rozważana tutaj teza brzmiałaby następująco: człowiek został stworzony przez Boga. Istotne wydaje się jednak doprecyzowanie: każdy człowiek został bezpośrednio stworzony przez Boga, w tym sensie, że w momencie poczęcia Bóg stwarza duszę konkretnego człowieka - co teologia określa mianem animacji bezpośredniej (Dogiel 1992). Z takiego ujęcia wypływają bardzo daleko idące konsekwencje, także pedagogiczne. Skoro każdy człowiek u początku swojego istnienia zetknął się z Nieskończoną Miłością, która powołała go do istnienia i która stanowi ontologiczną podstawę jego bytu, to trudno byłoby przyjąć, że ten fakt nie będzie wpływał na jego późniejsze funkcjonowanie. Bezpośrednie spotkanie $\mathrm{z}$ Bogiem musi w człowieku zostawić ślad, nawet jeżeli nie został on zapisany w jego świadomości (a nie mógł zostać, gdyż jego mózg jeszcze nawet nie zaczął się kształtować). Ten ślad tkwi głębiej, i z tego głębszego, niekoniecznie uświadomionego i racjonalnego poziomu oddziałuje na jego zachowania, choćby na zasadzie (często nieuświadomionej) tęsknoty.

René Habachi, libański myśliciel o egipskich korzeniach, rozważając kwestię ojcostwa, stwierdza, że jeżeli przyjmie się założenie, iż czyjeś pojawienie się na świecie było sprawą przypadku, to jego egzystencja jako człowieka będzie absurdalna. Inaczej jest przy założeniu, że jego zaistnienie było wynikiem wolnej, wypływającej z miłości decyzji rodziców. Tak więc geneza czyjegoś istnienia odciska piętno na jego egzystencji (Habachi 1968). Rozważane na poziomie psychologicznym stwierdzenie, że okoliczności towarzyszące początkom życia człowieka wpływają na jego późniejszą egzystencję jest prawdziwe, ale dość banalne. Inspirujące w myśli Habachiego wydaje się rozpatrywanie tej kwestii na poziomie ontologicznym. Przy czym z punktu widzenia prezentowanego tutaj, jest ona jednostronna, gdyż rozpatruje tylko ludzką stronę powoływania człowieka do istnienia. W świetle koncepcji animacji bezpośredniej, oprócz ludzkich rodziców (których wkład jest niezaprzeczalny) trzeba brać pod uwagę jeszcze jeden czynnik: stwórcze działanie Boga, które nigdy nie jest przypadkowe i którego motywacją zawsze jest miłość. Natomiast działania rodziców mogą wynikać z całego wachlarza motywacji, niekiedy zasadniczo odmiennych od tej boskiej (która, 
jak powiedziano, jest zawsze taka sama). W takiej sytuacji mamy do czynienia z pewnym dysonansem, rozdarciem już na poziomie ontologicznym, które - jak można się spodziewać - będzie się przejawiało też na poziomie egzystencjalnym (psychologicznym, emocjonalnym czy moralnym).

Jeśli jest tak, jak powiedziano powyżej, że każdy człowiek od początku nosi w sobie ślad Nieskończonej Miłości i tęsknotę za nią, to bardzo wiele (jeśli nie wszystkich) ludzkich zachowań można interpretować w kategoriach poszukiwania miłości. Czy poddają się takiej interpretacji na przykład zachowania agresywne członka osiedlowego gangu? Oczywiście! Ten młody, krótko ostrzyżony, ubrany w strój sportowy człowiek, na swoim własnym poziomie (poniżej poziomu racjonalnego) kalkuluje w następujący sposób: „Jeżeli ktoś się mnie boi, to jestem w jakiś sposób dla niego ważny i czuję się «trochę kochany»”. Ta kategoria „trochę kochany” jest istotna dla dalszych rozważań, dla których punktem wyjścia jest teza, że poszukiwanie miłości jest zasadniczym, najgłębszym motorem ludzkich działań. Ktoś inny może zamiast stroju sportowego ubierać garnitur i zdobywać coraz wyższe stanowiska, żeby mieć władzę nad innymi ludźmi i dzięki temu poczuć się ważny (trochę kochany), a jeszcze inny całą swoją energię poświęca na zarabianie pieniędzy, kalkulując (podświadomie), że gdy je zarobi, będzie z tego powodu podziwiany przez otoczenie - czyli poczuje się trochę kochany. Zachowania nieraz diametralnie różne można wyjaśnić tą samą potrzebą. To poszukiwanie przejawia się na miliardy bardzo indywidualnych sposobów, wśród których chyba najpowszechniejsze wydaje się właśnie gromadzenie zasobów - od wieków posiadające wymiar nie tylko użytecznościowy, ale i symboliczny (Baudrillard 2006). Dla niniejszych rozważań istotne jest, że to poszukiwanie może mieć różne natężenie (czasem może posiadać charakter rozpaczliwy) i przybierać formy zdeformowane, czyli przejawiać się w różnych zachowaniach dewiacyjnych. Mamy wtedy do czynienia z poszukiwaniem jakichś namiastek. Istnieje całe spektrum rzeczywistości, w których człowiek poszukuje spełnienia swojej egzystencji (szczęścia), niemal nieskończona ilość strategii i metod tego poszukiwania. Odpowiedź, dlaczego ten konkretny człowiek wybiera akurat te, jest zawsze bardzo złożona. Wpływa na to cały szereg czynników społeczno-kulturowych i indywidualnych. Na bardzo ogólnym poziomie można stwierdzić, że im bardziej 
niezaspokojona jest ta potrzeba, tym bardziej rozpaczliwe będzie poszukiwanie i z tym większym prawdopodobieństwem zwróci się ku poszukiwaniu namiastek, czyli będzie się przejawiać w zachowaniach dewiacyjnych. W wielu przypadkach wyjaśnieniem może być ontologiczny dysonans (wspomniany przy omawianiu myśli Habachiego), zwłaszcza, że bardzo często jest on wzmacniany przez późniejsze doświadczenia. Mówiąc krótko: człowiek, który u początku swego życia nie był chciany i kochany przez rodziców, także później bardzo często nie czuje się chciany i kochany. W takiej sytuacji prawdopodobnie nie będzie wierzył, że miłość w ogóle istnieje. Nie sprawi to, że w głębi serca przestanie za nią tęsknić, ale prawdopodobnie spowoduje, że będzie próbował w sposób dewiacyjny tę tęsknotę zaspokoić albo przynajmniej zagłuszyć.

"Sposób dewiacyjny" jest tutaj rozumiany szerzej niż w określeniu „zachowania dewiacyjne”. Owo rozpaczliwe poszukiwanie namiastek miłości obejmuje swoim zakresem całą dziedzinę zachowań dewiacyjnych i ryzykownych, ale jest pojęciem szerszym. Obejmuje też zachowania, które same w sobie są społecznie akceptowane albo nawet moralnie dobre, ale ze względu na niewłaściwą motywację przybierają charakter patologicznie intensywny. Przykładem może być praca zawodowa (działanie społecznie akceptowane i moralnie dobre) podejmowana $\mathrm{z}$ taką intensywnością, że okazuje się ona przeszkodą w realizacji innych wartości - np. niszczy życie rodzinne i zdrowie pracoholika. W świetle omawianej tu koncepcji antropologicznej wyjaśnieniem tej patologicznej intensywności byłaby pewna iluzja - najczęściej nie do końca uświadomione, złudne przekonanie, że sukces zawodowy i ekonomiczny mogą dać człowiekowi poczucie spełnienia, zaspokojenie jego najgłębszej potrzeby. Próba zaspokojenia potrzeby o charakterze duchowym przy użyciu materialnych dóbr skazana jest na niepowodzenie. Ale może to spowodować dwojaką reakcję: zmianę paradygmatu albo działanie według zasady „więcej tego samego". Fakt, że zdobyte dobra materialne nie uczyniły mnie szczęśliwym, mogę zinterpretować jako dowód, że muszę zdobyć ich znacznie więcej.

Opisane powyżej dewiacyjne poszukiwanie miłości jest oczywiście bliskie znaczeniowo kategorii grzechu. Katechizm Kościoła Katolickiego jego skutki określa jako „nieuporządkowane przywiązanie do stworzeń" (KKK 1472). W Biblii hebrajskiej rzeczownik 
hatț $\bar{a}^{\prime} \underline{t}$ (tlumaczony jako grzech) najczęściej występuje w znaczeniu „chybienie celu” (Kręcidło 2007). Oba te ujęcia, choć w różny sposób, akcentują ideę jakiegoś fundamentalnego błędu. W kategoriach egzystencjalnych można grzech określić jako poszukiwanie miłości zdeformowane w taki sposób, że człowiek szukając jej, w rzeczywistości oddala się od niej.

Zanim przejdziemy do omawiania szczególowych implikacji pedagogicznych twierdzenia, że miłość jest ontologiczną podstawą ludzkiego bytu i główną ludzką potrzebą, warto się zatrzymać chwilę nad uzasadnieniem tej tezy. Także dlatego, że niniejszym rozważaniom przyświeca ambicja wychodzenia poza ramy konfesyjne. Twierdzenie o stworzeniu ludzkiej duszy przez Boga jest tak samo niedowiedlne, jak samo istnienie Boga, które musi być rzeczywistością empirycznie niedowiedlną (ani niefalsyfikowaną). Nie chodzi tylko o to, żeby zostawić przestrzeń dla wiary, ale też o to, że jeśli byłoby inaczej, trzeba by przyjąć, że Bóg jest bytem skończonym, a my stworzyliśmy adekwatne (czyli obejmujące Go całkowicie) naukowe instrumentarium. Nieskończoność Boga, sprawiająca że wymyka się On narzędziom poznawczym skonstruowanym przez skończony ludzki rozum, nie powstrzymała całego zastępu myślicieli (ze św. Tomaszem na czele) przed formułowaniem argumentów za istnieniem Boga. Ich wysiłek nie był bezsensowny, gdyż przy użyciu rozumu da się wskazać argumenty za tym, że twierdzenie, iż Bóg istnieje, jest bardziej prawdopodobne, lepiej uzasadnione niż twierdzenie przeciwne.

Analogicznie sytuacja wygląda w przypadku twierdzenia, że Miłość jest ontologiczną podstawą ludzkiego bytu.

\section{Argumenty za koncepciq animacji bezpośredniej w odkryciach nauk szczegółowych}

Poniższy fragment będzie próbą naszkicowania kilku przykładów $\mathrm{z}$ różnych nauk społecznych, które w rozumieniu piszącego te słowa zdają się potwierdzać koncepcję animacji bezpośredniej. Nie są to oczywiście dowody w sensie ścisłym. Raczej przykłady, które można interpretować w ten sposób: nie mamy pewności (w sensie empirycznych dowodów), że człowiek został stworzony przez Nieskończoną 
Miłość, ale w wielu obszarach funkcjonuje tak, jakby rzeczywiście tak było.

Socjologia u swojego zarania przyniosła odkrycie zależności pomiędzy siłą więzi społecznych a liczbą samobójstw (Durkheim 2006). Oczywiście nie jest to jedyny czynnik, ale w skali makro okazuje się zasadniczy. Od badań Émile'a Durkheima minęło prawie półtora wieku i od tamtego czasu mogliśmy zaobserwować jeszcze jedną prawidłowość: liczba samobójstw rośnie wraz z rozwojem cywilizacyjnym danej społeczności (Zwoliński 2013). Okazuje się więc, że kiedy poprawiają się warunki życia, ale jednocześnie słabną więzi społeczne, odsetek ludzi ekstremalnie nieszczęśliwych rośnie. Z punktu widzenia prezentowanej tu antropologii wyjaśnienie wydaje się proste: człowiek czuje się szczęśliwy, czuje że jego życie ma sens wtedy, kiedy kocha i czuje się kochany. To jest nasza zasadnicza potrzeba.

Psychologia społeczna, czyli dziedzina zajmująca się badaniem wzajemnych wpływów międzyludzkich, już swoim istnieniem i każdym szczegółowym odkryciem potwierdza, że człowiek z natury jest istotą społeczną (Aronson 2002). Istnienie w nas szeregu mechanizmów sprawiających, że dostrajamy się do oczekiwań i zachowań otaczających nas ludzi można interpretować w ten sposób: człowiek spontanicznie poszukuje akceptacji i poczucia wspólnoty z innymi, gdyż dzięki temu czuje się trochę kochany.

Analiza transakcyjna opisuje szkolne interakcje jako system gier, w wyniku których uczeń otrzymuje "głaski” - nagrody i pochwały lub „kolczatki” - kary i upomnienia (Jagieła 2007). Obserwacje poczynione $\mathrm{w}$ trakcie nauczycielskiej praktyki piszącego te słowa wielokrotnie potwierdziły, że rzeczywiście uczniowie (zwłaszcza ci, którym rzadko udaje się otrzymać "głaski”) aktywnie zabiegają o „kolczatki”. Kara jest dla nich formą nagrody, bo kiedy są karani czy upominani, ktoś zwraca na nich uwagę - czują się dostrzeżeni, czyli trochę kochani.

$\mathrm{Z}$ badań dotyczących profilaktyki wynika bardzo jednoznacznie, że więzi rodzinne są najważniejszym czynnikiem profilaktycznym, najlepiej chroniącym przed całym spektrum zachowań ryzykownych (Wojcieszek 2019; Grzelak 2009, 2015). Była już o tym mowa - im bardziej człowiek czuje się kochany, tym mniej rozpaczliwie szuka namiastek szczęścia. 


\section{Animacja bezpośrednia a edukacja szkolna}

Rozumienie człowieka jako istoty, dla której sprawą absolutnie fundamentalną są relacje interpersonalne mogłoby się przyczynić do odwrócenia ( $\mathrm{w}$ moim rozumieniu we właściwą stronę) hierarchii celów edukacyjnych. Zadania nauczyciela i szkoły opisuje się w kategoriach działalności dydaktyczno-wychowawczej, przy czym w praktyce pierwszemu członowi tego wyrażenia przypisuje się nieporównywalnie większe znaczenie. Przyczyny takiego stanu rzeczy są złożone, jedną z nich jest fakt, że efekty pracy dydaktycznej są znacznie łatwiej mierzalne, w związku z czym to głównie $z$ nich nauczyciele są rozliczani i na nich się skupiają. Skutkiem tego stanu rzeczy jest zaniedbywanie spraw najważniejszych $\mathrm{z}$ powodu inwestowania większości energii w sprawy drugorzędne. Zarówno z punktu widzenia indywidualnego, jak i społecznego znacznie ważniejsze jest to, jakim człowiekiem będzie w przyszłości nasz uczeń (a co za tym idzie, jakie relacje będzie tworzył), niż to, jaki zasób wiedzy i umiejętności posiądzie. Dla przykładu: jeśli wyposażymy go w solidne kompetencje informatyczne, ale będzie narkomanem - jaki pożytek dla niego i dla społeczeństwa z tych kompetencji? Co więcej, jeśli wyposażymy go w rozległą wiedzę z chemii i fizyki, a on będzie psychopatą, to dla społeczeństwa jego kompetencje mogą okazać się szkodliwe.

Warto się też zastanawiać, ile miejsca w samej działalności wychowawczej zajmuje rozwijanie tej absolutnie kluczowej kompetencji - umiejętności tworzenia głębokich więzi międzyludzkich. Nie chodzi tutaj o uczenie współpracy (o tej potrzebie rzeczywiście mówi się coraz więcej), tylko o coś znacznie głębszego. Współpraca, czyli wspólne działanie, aby osiągnąć jakiś praktyczny cel, jest oczywiście umiejętnością ważną i przydatną. Ale współpracować można (czasem trzeba) z ludźmi, z którymi nie łączą mnie żadne głębokie więzi (nie kocham ich ani oni mnie). Jeśli okazałoby się, że nasze młode pokolenie w dorosłym życiu będzie sprawnie współpracować, przyśpieszając $\mathrm{w}$ ten sposób rozwój gospodarczy, ale jednocześnie będzie zbiorem wyalienowanych osób, które nikogo nie kochają, to uważam, że jako społeczeństwo poniesiemy porażkę. Odsetek samobójstw będzie jej miarą.

W kierunkach realizacji polityki oświatowej państwa nie znajdziemy raczej zapisu: „rozwijanie umiejętności tworzenia głębokich 
i trwałych relacji międzyludzkich”. Może to zresztą świadczyć o pokornej roztropności decydentów. Niestety, albo na szczęście, szkoła ma ograniczony wpływ na młodego człowieka. Nie jest w stanie ukształtować go dowolnie i w każdej dziedzinie. Można co prawda zaobserwować nawet dość powszechne przekonanie, że odpowiednio zorganizowana edukacja będzie lekiem na całe zło tego świata (Postman 2002), ale sądzę, że jest ono skrajnie naiwne. Szkoła nie jest jedynym, ani nawet nie najważniejszym środowiskiem wychowawczym. W dziedzinie, o której tutaj mowa, nieporównywalnie większą rolę do odegrania ma rodzina stanowiąca najbardziej naturalną przestrzeń, gdzie człowiek może doświadczać głębokich więzi z innymi i przez to uczyć się je tworzyć. Temat ten zostanie poruszony szerzej poniżej, gdyż dla klarowności wywodu wydaje się korzystne omówienie jeszcze jednej kwestii związanej ze szkołą.

Kolejną dziedziną, w której adekwatna antropologia może być pomocna i inspirująca w myśleniu o szkole jest sprawa poszczególnych narzędzi i ich znaczenia w działalności dydaktyczno-wychowawczej. W działalności wychowawczej kluczowym czynnikiem, można powiedzieć najważniejszym narzędziem, jest osobowość nauczyciela (Kupisiewicz 1994), a jej kształtowanie jest pierwszym zadaniem ukazywanym przez deontologię pedagogiczną (Tchorzewski 2016). Rzeczywiście, trudno oczekiwać, żeby np. niesamodzielny nauczyciel kształtował samodzielnych uczniów (Śnieżyński 1995; Kawecki 2004). Nauczyciele - nawet jeśli myślą, że wyłącznie nauczają - zawsze wychowują, choć nie zawsze w sposób świadomy (Mastalski 2005). Co więcej, wiadomo nie od dziś, że osobowość nauczyciela rzutuje w znaczący sposób także na skuteczność jego pracy ściśle dydaktycznej (Okoń 1968; Kupisiewicz 1972; Márquez, Rossa 2019). Dzięki pogłębianiu wiedzy o ludzkim mózgu dowiadujemy się coraz więcej o znaczeniu czynników interpersonalnych w procesie uczenia się, o społecznym charakterze tego organu, a także o istnieniu i funkcjonowaniu modułów mózgu aktywowanych tylko w kontakcie z żywym człowiekiem (Márquez, Rossa 2019; Żylińska 2013). O pierwszorzędnym znaczeniu cech osobowościowych nauczyciela wiemy coraz więcej. Ale czy wyciągamy z tej wiedzy odpowiednie wnioski praktyczne? Czy w systemie przygotowania, a później selekcji do zawodu nauczyciela czynniki osobowościowe traktowane są priorytetowo? Chyba każdemu, kto zna rzeczywistość polskiego 
szkolnictwa pytanie to wyda się retoryczne. Można się też zastanawiać, czy refleksja pedagogiczna poświęca tym zagadnieniom wystarczająco dużo uwagi.

\section{Animacja bezpośrednia a wychowanie w rodzinie}

Fundamentalne znaczenie rodziny w wychowaniu i jej zasadniczy wpływ na rozwój dziecka jest w psychologii i pedagogice sprawą dość oczywistą. Nowe gałęzie wiedzy o człowieku (np. neurobiologia interpersonalna) pozwalają nam pogłębiać rozumienie mechanizmów tego wpływu (Márquez, Rossa 2019). Warto zaznaczyć, że oprócz wszystkich psychologicznych czynników predestynujących rodzinę do roli podstawowego środowiska wychowawczego, z koncepcji animacji bezpośredniej wynika jeszcze jeden (można go nazwać ontologicznym): jest ona przestrzenią tego pierwszego spotkania z Miłością (która stworzyła człowieka). Zasadniczą tezę niniejszych rozważań można by streścić w ten sposób: miłość stanowi ontologiczną podstawę i najgłębszy sens ludzkiej egzystencji, a więc to miłość winna stanowić jednocześnie cel i metodę wychowania. Innymi słowy, wychowanie (jeśli ma być pomocą w rozwoju i urzeczywistnianiu pełni człowieczeństwa) powinno pomagać wychowankowi, poprzez doświadczenie bycia kochanym uczyć go kochać innych.

Czy współczesna rodzina w zadowalającym stopniu wypełnia tę wychowawczą misję? Czy przykłada do niej właściwą wagę? Diagnoza jest niezwykle trudna. Pomijając nawet problemy z ustaleniem kryteriów (co uznać za zadowalający stopień?) i wskaźników, mówiąc o wychowaniu we współczesnej rodzinie mamy do czynienia z ogromną różnorodnością postaw. Badania Fundacji Mamy i Taty zidentyfikowały cztery zasadnicze typy rodzin. Jeden z nich stanowi „rodzina projektująca”, która kładzie duży nacisk na karierę dziecka i przenosi na grunt rodzinny system motywacyjny typowy dla korporacji, oparty na krótkoterminowych celach i nagrodach. Biegunowo odmienny typ stanowi rodzina (najczęściej wielodzietna), w której rodzice poprzez intensywny kontakt starają się wspierać dzieci i kompensować im niski status materialny (Woliński 2016). W wyniku segmentalizacji życia społecznego, przypominającego plaster miodu (Nowak-Dziemianowicz 2012), mamy do czynienia z coraz większą różnorodnością postaw. Dodatkowo możemy obserwować nie tylko 
różne tempo przemian w różnych dziedzinach (Bell 1998), ale wręcz przeciwstawne trendy w różnych segmentach społeczeństwa. Mówiąc o współczesnej rodzinie, możemy bardzo często zaobserwować, że zasadniczym oczekiwaniem rodziców wobec dzieci jest, aby były jak najmniej absorbujące (Nowak-Dziemianowicz 2006). Z drugiej strony można też zauważyć zjawisko „mikrosterowania” - czyli takie postawy rodziców, którzy ogromnym nakładem czasu i energii starannie planują i kontrolują niemal każdy krok dziecka, najczęściej pod kątem rozwijania umiejętności postrzeganych jako pomocne w przyszłej karierze (Honoré 2011). Pomimo zasadniczej odmienności tych rodzicielskich postaw, można przypuszczać, że efekty wychowania w opisywanej tu dziedzinie (przygotowanie do miłości) nie będą zbyt dobre. Wszelkie uogólnienia w odniesieniu do tak złożonej dziedziny, jaką są relacje rodzinne, narażone są na ryzyko pominięcia istotnych zjawisk i trendów przeciwnych tym dominującym. Gdyby (pamiętając o powyższym) pokusić się o nakreślenie zasadniczej tendencji, raczej trudno byłoby mówić o optymizmie. Generalnie relacje instrumentalne wypierają te głęboko ludzkie - autoteliczne (Sztompka 2012) i nawet w przypadku związków intymnych więzi oparte na wierności i wdzięczności zastępuje kontrakt i wymiana (Woliński 2016). W porównaniu z poprzednimi pokoleniami dzisiejsze dzieci mają znacznie lepsze warunki materialne, ale gorsze warunki do uczenia się miłości.

Co możemy więc zrobić? Biorąc pod uwagę, że źródłem negatywnych zjawisk są potężne procesy społeczne (z rozwojem konsumpcjonizmu na czele), przeciwdziałanie im będzie niezwykle trudne. Co nie znaczy, że nie należy próbować. Taką, godną docenienia próbą, są kampanie społeczne promujące wartość rodzicielstwa i właściwe postawy. Również szkoły nie powinny ustawać w niezwykle trudnej działalności, jaką jest pedagogizacja rodziców i uwrażliwianie ich na znaczenie pielęgnowania relacji z dziećmi. Państwo - we właściwym sobie zakresie - powinno wzmacniać instytucję rodziny i dbać o jej trwałość. I wreszcie Kościół - realizując swoją zasadniczą misję, której elementem jest propagowanie hierarchii wartości stawiającej miłość ponad dobrami materialnymi czy sukcesem zawodowym - może odegrać tutaj niebagatelną rolę. Tak jak państwo ma narzędzia, żeby tworzyć odpowiednie warunki (można powiedzieć zewnętrzne) dla właściwego funkcjonowania rodzin, tak również Kościół ma własne 
narzędzia (i zadanie) do kształtowania człowieka przede wszystkim od wewnątrz, tj. jego przekonań i postaw.

Jest to też wyzwanie dla teoretyków, i choć co prawda ich prace nie mają bezpośredniego przełożenia na postawy rodzicielskie, to jednak w dłuższej perspektywie refleksja naukowa wpływa na poglądy, a co za tym idzie na postawy mas. Jeśli zaprezentowane powyżej rozważania są właściwe, to miłość winna się stać kluczową kategorią dyskursu pedagogicznego. Być może udałoby się dzięki temu nieco odprofesjonalizować działalność wychowawczą. Taki postulat może się wydawać na pierwszy rzut oka absurdalny, ale nie chodzi tu o to, żeby wychowawcy zachowywali się mniej profesjonalnie, lecz o to, żeby wychowanie w mniejszym stopniu cedować na profesjonalistów. Mamy do czynienia ze zjawiskiem postrzegania wychowania jako domeny profesjonalistów i tendencją do przekazywania im wychowawczych zadań i odpowiedzialności (Woliński 2016). Wskazane wydaje się przeciwdziałanie takiemu zanikowi poczucia odpowiedzialności wychowawczej rodziców.

Zanik poczucia odpowiedzialności wychowawczej jest zjawiskiem, nad którym warto się chwilę zatrzymać. Ma ono wiele wymiarów. Po pierwsze, możemy obserwować narastającą niechęć w ogóle do jej podejmowania, co widać np. w zjawisku coraz mniejszej dzietności. W konsumpcyjnej kulturze wiecznej zabawy próg dojrzałości, rozumianej jako przekroczenie odpowiedzialności indywidualnej i rozszerzenie jej na drugiego człowieka, jawi się wielu ludziom nie jako szansa rozwojowa niosąca możliwość dopełnienia własnego człowieczeństwa (Ablewicz 2003), ale raczej jako zagrożenie dla najwyższych wartości - beztroski i zabawy (Nowak-Dziemianowicz 2006). Filozofia indywidualizmu, w której naczelną wartością jest autonomia (Nowak-Dziemianowicz 2012), a zasadniczym zobowiązaniem zdanego wyłącznie na siebie człowieka jest troszczenie się głównie o siebie (Tchorzewski 2002), na pewno nie sprzyjają podejmowaniu odpowiedzialności za innych, czyli rodzicielstwu.

Powyższe zjawiska wpływają także na ludzi, którzy już są rodzicami, osłabiając ich gotowość do podejmowania rodzicielskiej odpowiedzialności w sensie osłabiania ich zaangażowania. Kalkulacja (prawdopodobnie najczęściej nietematyzowana, a raczej podświadoma) może przebiegać w taki sposób: „Nie mogę już uniknąć zostania rodzicem i strat (w dziedzinie wygody i doświadczanych 
przyjemności) oraz zobowiązań z tym związanych, ale zawsze mogę te straty zminimalizować, a zobowiązania uczynić mniej dotkliwymi. Mogę to zrobić w prosty i społecznie akceptowalny sposób - przekazując wychowanie mojego dziecka w ręce specjalistów. Zresztą to dla wszystkich - a przede wszystkim dla dziecka - będzie lepsze!". Współczesny człowiek może $\mathrm{w}$ to szczerze wierzyć. Po pierwsze, w konsumpcyjnej aksjologii stawia się znak równości pomiędzy tym, co łatwe i przyjemne, a tym, co dobre i słuszne. Po drugie, wszechobecny przekaz kulturowy, w którym człowiek jest odpowiedzialny wyłącznie przed sobą i za siebie samego, a samorealizacja i samorozwój (rozpatrywany raczej w kategoriach zawodowych niż moralnych czy duchowych) jest nie tylko najwyższym prawem, ale wręcz obowiązkiem, może u człowieka obarczonego odpowiedzialnością za innych, zobowiązaniami pochłaniającymi czas i energię, a wiec utrudniającymi wypełnienie tego najważniejszego zobowiązania (wobec siebie i własnej samorealizacji), powodować poczucie pewnego dyskomfortu, a nawet krzywdy. Rodzicielstwo z jego wymaganiami może więc być postrzegane jako sytuacja, której w imię odpowiedzialności (za siebie) należy unikać.

Przyczyny osłabiania rodzicielskiej odpowiedzialności mogą być jeszcze inne. Aksjonormatywny chaos, w którym żyjemy bez stałych punktów odniesienia, powoduje poczucie zagubienia także wśród rodziców. Paweł Woliński zjawisko przekazywania odpowiedzialności wychowawczej specjalistom omawia w kontekście badań, które pokazały, że blisko 40\% rodziców deklaruje całkowitą rezygnację nawet z prób wychowywania swoich dzieci, a 30\% jako przyczynę wskazuje właśnie poczucie zagubienia wyrażane stwierdzeniem: „Sam nie wiem jak żyć, więc jak miałbym wychowywać” (Woliński 2016). Na to ogólnospołeczne poczucie zagubienia nakłada się jeszcze poczucie specyficznie rodzicielskie. Wielu współczesnych rodziców nie tylko gubi się w płynnym świecie rozmytych wartości, ale dodatkowo czuje się zagubionych w kwestiach ściśle wychowawczych. Innymi słowy, czują, że nie wiedzą jak żyć, a jeszcze bardziej jak wychowywać. $Z$ jednej strony wpływa na to (dotykające wszystkich wychowawców) przeciążenie normatywne, czyli na wiedzę zawierającą ogromny stopień i zakres wartościowania (Nowak-Dziemianowicz 2012). Rzeczywiście, można odnieść wrażenie, że współczesny wychowawca powinien być zawsze piękny, młody, uśmiechnięty i zrelaksowany, a do 
tego mieć bardzo dużo czasu i niewyczerpane pokłady cierpliwości. Jeśli nie spełni któregoś z tych warunków, to spowoduje nieodwracalne szkody w psychice swego wychowanka. Skłonność do wychowywania dzieci osłabia dodatkowo skutecznie zaszczepiona przez antypedagogów podejrzliwość co do zasadności jakichkolwiek wpływów ze strony dorosłych (Śliwerski 2004). Warto zauważyć, że antypedagogiczna antropologia, głosząca że dziecko, będące istotą cudowną i kompletną, samo najlepiej zna swoje potrzeby, w związku z czym nie istnieje żadna uprawniona odpowiedzialność za innych, bo jest ona zawsze krzywdzącą uzurpacją (Tchorzewski 2017) i świetnie współbrzmi z filozofią indywidualizmu. Współczesny rodzic słyszy więc $\mathrm{z}$ jednej strony, że jedyne zobowiązania, od których nie wolno się uchylić to te, jakie się ma wobec samego siebie; a $z$ drugiej strony, że postrzeganie siebie jako osoby odpowiedzialnej (a więc też uprawnionej do decydowania) za dziecko stanowi zamach na jego ( $\mathrm{tj}$. dziecka) autonomię, godność i podstawowe prawa człowieka. Trudno się dziwić, że wielu rodziców stwierdza: „To ja jednak zrezygnuję”.

Kolejną przyczyną osłabiania rodzicielskiej odpowiedzialności może być technicyzacja naszego życia. W coraz większym stopniu jesteśmy otoczeni przez urządzenia, których obsługa - szczególnie w przypadku awarii - wymaga pomocy specjalisty. Żeby zobrazować tę przemianę: mój ojciec naprawiał Poloneza przy użyciu prostych narzędzi. Ja nie podjąłbym się w swoim samochodzie usunięcia żadnej usterki bez pomocy specjalisty (uzbrojonego w fachową wiedzę i profesjonalne narzędzia). Technicyzacja powoduje, że coraz większą część naszego świata życia codziennego stanowią urządzenia techniczne - działające w sposób zalgorytmizowany, a w razie awarii wymagające interwencji specjalisty. Być może w pewien sposób przenosimy to codzienne doświadczenie na świat ludzki (w tym na wychowanie). Można spotkać w pedagogice takie traktowanie metod czy technik wychowania, jakby miały one stanowić algorytm niezawodnie prowadzący do osiągnięcia określonego celu (Tchorzewski 2016). W praktyce wychowawczej niestety też można zaobserwować tego typu myślenie: dziecko się „zepsuło”, nie działa prawidłowo niech specjalista je „naprawi”. Tym specjalistą może być zawodowy wychowawca albo lekarz aplikujący odpowiednią pigułkę. Czyż rosnąca geometrycznie liczba recept na Ritalin - „magiczne pigułki” 
zamieniające nadpobudliwe dzieci w "grzeczne aniołki” (Giddens 2012) nie jest wynikiem takiego myślenia?

Opisane powyżej myślenie zawiera fundamentalny błąd: dziecko nie jest urządzeniem, którego „obsługę” da się zalgorytmizować i (z korzyścią dla wszystkich) powierzyć specjalistom, ale człowiekiem, który przede wszystkim potrzebuje czuć się kochany.

\section{Podsumowanie}

Fundamentem każdej sensownej refleksji pedagogicznej jest mniej lub bardziej dookreślona i jasno wyrażona - odpowiedź na pytanie: kim jest człowiek? Chrześcijańska antropologia postrzega człowieka jako istotę stworzoną z miłości i powołaną do miłości. Takie spojrzenie pozwala przywracać wychowaniu głęboko ludzki charakter.

Odzyskanie tego głęboko ludzkiego wymiaru nie tylko wychowania, ale i życia w ogóle - oznaczające przywrócenie człowiekowi prymatu nad rzeczą, a miłości prymatu nad wygodą czy przyjemnością może stanowić remedium na wiele społecznych kryzysów. Kryzysów na tyle poważnych, że jeżeli jako społeczeństwo nie znajdziemy drogi wyjścia, to przyszłym pokoleniom dramatycznie będzie brakować środowisk, w których mogłyby się uczyć miłości. Zresztą prawdopodobnie dramatycznie będzie brakować następnych pokoleń.

\section{Bibliografia}

Ablewicz K. (2003). Teoretyczne i metodologiczne podstawy pedagogiki antropologicznej. Studium sytuacji wychowawczej, Kraków: Wydawnictwo UJ.

Aronson E. (2002). Cztowiek istota spoteczna, przel. J. Radzicki, Warszawa: Wydawnictwo Naukowe PWN.

Baudrillard J. (2006). Spoteczeństwo konsumpcyjne jego mity i struktury, przeł. S. Królak, Warszawa: Wydawnictwo „Sic!”.

Bell D. (1998). Kulturowe sprzeczności kapitalizmu, przeł. S. Amsterdamski, Warszawa: Wydawnictwo Naukowe PWN.

Dogiel G. (1992). Antropologia filozoficzna, Kraków: Instytut Teologiczny Księży Misjonarzy.

Durkheim É. (2006). Samobójstwo. Studium z socjologii, przeł. K. Wakar, Warszawa: Oficyna Naukowa. 
Giddens A. (2012). Socjologia. Wydanie nowe, przeł. O. Siara, A. Sulżycka, P. Tomanek, Warszawa: Wydawnictwo Naukowe PWN.

Grzelak S. (2009). Profilaktyka ryzykownych zachowań seksualnych mtodzieży. Aktualny stan badań na śriecie $i$ w Polsce, wyd. 2 rozszerzone, Kraków: Wydawnictwo Rubikon.

Grzelak S. (red.) (2015). Vademecum skutecznej profilaktyki. Przewodnik dla samorządowców i praktyków oparty na wynikach badań naukowych, wyd. 2, Warszawa: Ośrodek Rozwoju Edukacji.

Habachi R. (1968). U źródet cztowieczeństwa, przeł. W. Sukiennicka, Warszawa: Instytut Wydawniczy Pax.

Honoré C. (2011). Pod presją. Dajmy dzieciom święty spokój!, przeł. W. Mitura, Warszawa: Drzewo Babel.

Jagieła J. (2007). Narcystyczna szkota. O psychologicznej rzeczywistości szkoty, Kraków: Wydawnictwo Rubikon.

Katechizm Kościoła Katolickiego (1994). Poznań: Pallottinum.

Kawecki I. (2004). Wiedza praktyczna nauczyciela (studium etnograficzne), Kraków: Oficyna Wydawnicza „Impuls”.

Kręcidło J. (2007). Dlaczego Bóg uczynit Chrystusa grzechem (2 Kor 5,21)?, „Ruch Biblijny i Liturgiczny”, t. 60, nr 4, s. 273-286.

Kupisiewicz C. (1972). Niepowodzenia dydaktyczne. Przyczyny oraz niektóre środki zaradcze, wyd. 5, Warszawa: PWN.

Kupisiewicz C. (1994). Podstawy dydaktyki ogólnej, Warszawa: Polska Oficyna Wydawnicza „BGW”.

Márquez M.I., Rossa C. (2019). Wychowanie interpersonalne, „Paedagogia Christiana", nr 1(43), s. 419-436.

Mastalski J. (2005). Szkolne interakcje zaburzajace skuteczne wychowanie, Kraków: Wydawnictwo Naukowe PAT.

Nowak M. (2001). Podstawy pedagogiki otwartej. Ujęcie dynamiczne w inspiracji chrześcijańskiej, Lublin: Redakcja Wydawnictw KUL.

Nowak-Dziemianowicz M. (2006). Doświadczenia rodzinne w narracjach. Interpretacje sensów i znaczeń, wyd. 2, Wrocław: Wydawnictwo Naukowe Dolnośląskiej Szkoły Wyższej Edukacji TWP we Wrocławiu.

Nowak-Dziemianowicz M. (2012). Edukacja i wychowanie w dyskursie nauki i codzienności, Kraków: Oficyna Wydawnicza „Impuls”.

Okoń W. (1968). Zarys dydaktyki ogólnej, wyd. 3, Warszawa: Państwowe Zakłady Wydawnictw Szkolnych.

Wojcieszek K. (2013). Pedagogiczne implikacje grupowych interwencji krótkoterminowych, Kraków: Wydawnictwo Rubikon.

Postman N. (2002). Zabawić sie na śmierć. Dyskurs publiczny w epoce show-businessu, przeł. L. Niedzielski, Warszawa: Warszawskie Wydawnictwo Literackie Muza SA.

Ryk A. (2012). W poszukiwaniu pedagogicznego arché. Zarys systemów pedagogicznych, Kraków: Wydawnictwo Naukowe UP. 
Sztompka P. (2012). Socjologia. Analiza spoteczeństwa, wyd. 2, Kraków: Wydawnictwo Znak.

Śliwerski B. (2004). Wspótczesne teorie i nurty wychowania, wyd. 4, Kraków: Oficyna Wydawnicza „Impuls”.

Śnieżyński M. (1995). Nauczanie wychowujące, Kraków: Wydawnictwo Naukowe PAT.

Tchorzewski A.M. de (2002). Wychowanie na tle różnych koncepcji rzeczywistości spotecznej, [w:] A.M. de Tchorzewski (red.), Wspótczesne konteksty wychowania. W kregu pytań i dyskusji, Bydgoszcz: Wers.

Tchorzewski A.M. de (2016). Wstęp do teorii wychowania, Kraków: Akademia Ignatianum; Wydawnictwo WAM.

Tchorzewski A.M. de (2017). Imperatyw pedagogiczny jako element strategii wychowawczej, „Studia Paedagogica Ignatiana”, t. 20, nr 2, s. 61-84.

Wojcieszek K. (2019). Program profilaktyczny dla rodziców „Dżungla”. Struktura, zasady i możliwości zastosowania, „Studia Paedagogica Ignatiana”, t. 22 , nr 3, s. 39-50.

Woliński P. (2016). Abdykacja rodziców z funkcji wychowawczych. Wykład wygłoszony podczas III Kongresu Życia i Rodziny 31.03.2016 r. w Warszawie, https://www.youtube.com/watch?v=0mCXtQw2pA4.

Zwoliński A. (2013). Samobójstwo jako problem osobisty i publiczny, Kraków: Wydawnictwo WAM.

Żylińska M. (2013). Neurodydaktyka. Nauczanie i uczenie się przyjazne mózgowi, Torun: Wydawnictwo Naukowe UMK.

\section{ADRES DO KORESPONDENCJI}

Mgr Mateusz Melchior Mazurek

Uniwersytet Pedagogiczny im. KEN w Krakowie

Wydział Nauk Społecznych

Instytut Nauk o Wychowaniu

e-mail: anawim.j@gmail.com 